Original Research Paper

\title{
Assessment of Urban Residential Land Use, Challenges and Control in Orita Obele Housing Estate, Akure, Nigeria
}

\author{
${ }^{1}$ Muyiwa L. Akinluyi, ${ }^{2}$ Oluwatoyin O. Adeleye, ${ }^{3}$ OLA Olumide S. and ${ }^{4}$ Akinniyi Tunde Akinyemi \\ ${ }^{I}$ Department of Architecture, Afe Babalola University, Ado-Ekiti (ABUAD), Ekiti-State, Nigeria \\ ${ }^{2}$ Department of Architecture, Joseph Ayo Babalola University (JABU), Osun-State, Nigeria \\ ${ }^{3}$ Department of Estate Management, University of Jos (UNIJOS), Plateau-State, Nigeria \\ ${ }^{4}$ Ministry of Works and Transport, Ajilosun, Ado-Ekiti, Ekiti-state, Nigeria
}

\author{
Article history \\ Received: 02-04-2020 \\ Revised: 30-05-2020 \\ Accepted: 30-07-2020 \\ Corresponding Author: \\ Muyiwa L. Akinluyi \\ Department of Architecture, \\ Afe Babalola University, Ado- \\ Ekiti (ABUAD), Ekiti-State, \\ Nigeria \\ Email: akinluyimuyiwa@gmail.com
}

\begin{abstract}
This study examined the various challenges involved in urban residential land use and control in Orita Obele housing estate, Akure OndoState Nigeria with a view to providing information that will inform decision making on land and building development in the study area. Questionnaire were administered on One Hundred and Sixty-eight (168) housing units selected using a systematic random sampling. Data were analyzed using Descriptive, Bivariate and Multivariate Analysis. The result of the survey indicates that majority of the land owners (53.5\%) acquired between (1) one and (3) three plots of land for their housing development in the study area and many of these residential land users (36.9\%) and (20.2\%) developed only (1) one and (2) two plots respectively for residential purpose. It was further discovered that majority $(86.9 \%)$ of the land owners had gone through the approval processes of their survey by signing their survey plan with the relevant government agency in the state. However, $53.6 \%$ of the landowners are of the opinion that undue delay in signing the survey plan from state surveyor general had very low influence on their construction activities. The results from this study suggested more affordable residential land to be provided by the state government or stakeholders for adequate and proper planning of the housing environment to give room for more quality air space and comfort within the environment. The study will be useful as reference materials to inform policy for land and building development control in the residential environment, Akure Ondo-State.
\end{abstract}

Keywords: Urban Residential, Land Use, Building, Development, Control, Akure

\section{Introduction}

Urbanization according to (Mayaki, 2007) is the various process and activities required to transform a rural setting into a modern society which serves the various zonal economic needs of an industrial (rather than agricultural) community. Akinluyi and Adedokun (2014) however described urbanization as the proportion of total population or area in cities. Urbanization represent the rate at which the urban proportion is increasing. Urban areas are a product of human invention which people have evolved as a means of organizing their existence. The development and growth of urban areas is generally referred to as urbanization. Urbanization occurs naturally from individual and corporate efforts to reduce time and expense in commuting and transportation while prospecting for jobs, education, housing, etc., within urban area (Akinluyi and Adedokun,
2014). Living in cities permits individuals as well as families to take advantage of various opportunities such as of proximity to place of work, availability of shopping malls and accessibility to local and international airports etc., which are hitherto not available in a rural setting.

People move into cities to seek economic opportunities thereby increasing the need for land and housing development in the city centers. The influx of people to the most urbanized centers has increased land and housing demand. Therefore, available land needs to be well planned and managed to accommodate adequate spaces for housing developments. Housing development control is thus the practical aspect of physical planning which affects the life of general populace (Akingbohungbe, 2005). It involves rules setting and the enforcement of such rules in the use of land to achieve set goal and objectives. Such rules include ensuring; harmonious growth and development, sustainable 
environmental policy, prevention of overloading of infrastructures, protection of individual rights, Improvements of living standards, orderly and judicious use of land and safety of lives and structures (Akingbohungbe, 2005).

The land development systems, focused on process that converts or reconverts space and adapts it for human use in the pursuit of activities. The principal agent and subsystem process of land development according to (Omirin, 2002) includes; predevelopment landowners, developers, consumers, financial intermediaries and public agencies. The inhibitors of land development system also include; politics, funding, corruption, ignorance, lack of planning facilities and deficient strategy (Omirin 2002).

The process of development control therefore involves a technique for the systematic anthology of expert quantitative examination and qualitative judgment of project land use and property development capability which involved planning standard technique.

This study examined the various challenges involved in the building development and its control using survey method. Information relating to the various challenges involved in the process of building development and its approval was examined in orita obele housing estate in Akure, Ondo-state, Nigeria.

\section{Housing, Development Control and Its Challenges}

The meaning of control is a standard that is needed to be achieved in a certain condition. Any housing development need to be controled in order to create a good place. Nigerian urban and regional planning decree 88 of 1992 conceived the mechanism of development control in the context of all form of development in relation to building engineering, mining or other corporations in, on, over or under any land or making of any environmentally significant change in the use of any land, or demolition of buildings, including the felling of trees and the placing of free standing erections used for the display of advertisement on the land (FRN, 1992). It is a mechanism through which entire process of urban development is regulated to achieve the objective of promoting overall benefit of the society and creating a distinct image of the city. It includes guiding the development and use of land, curbing misuse of land and promoting rational and orderly development of built en vironment.

According to (Robert, 1975), the planning standards include prescriptive and regulatory standards, which provide guide specifications and requirements for development and official instrument designed to safeguard, regulate, conserve and disburse land or part thereof in the overall interest of the community for an orderly growth. It stipulates adequate standards for all aspects of planning, land-use and construction to avoid function conflicts, infrastructural stress and deterioration of environment quality. The provision or standards are made under urban and Regional Planning Law, Sub division Regulations, Zoning Codes and Building Byelaws. They are enforceable by the planning authority with police protection for effectiveness. However, planning standards will help to avoid conflicts in land or building use. The use of planning standards is to ensure that every developments project is unfailing, comfortable and safe. The residential/housing environments in Orita Obele Housing Estate Akure need to be guided by adequate development control through standard planning techniques.

\section{The Residential Land Use Planning}

Land is used for several purposes ranging from recreational, commercial, residential, industrial, religious, etc., the combination of these uses depends on their relationship. The determination of residential location decisions are of significance for two basic reasons. First, housing is the most important type of urban land use (about one and a half) of the urban total land. Secondly, it is the most important item in the consumers' expenditure (up to one quarter of the consumer expenditure) (Omirin, 2002; Owoeye and Adedeji, 2015). Olomolaiye (1999) observed that residential land is the main, if not the only asset held by the poor and their ability to claim and sell it is a critical element in social and economic development. In addition, (Chukwujekwu, 2006) argued that land for residential is not just only basic to life but it also contains all necessities for life to exist and a tool for obtaining social prestige, economic security and political power. However, land use planning provides the basis on which a locality could establish what its pattern of land use ought to be. In this perspective, urban spatial structure is a conjunctive outcome of the functioning of market and political processes, the one providing the means by which government articulates and pursues the common interest (Omirin, 2002).

The elements of common interest affecting the land use pattern of an urban area include health and safety, convenience, efficiency, environmental quality (Owoeye and Adedeji, 2015). The unauthorized land use may include; the development with invalid extension representing building with valid permit and constructed as approved but later altered to accommodate other functions (Akingbohungbe and Folorunso, 2005; Adedeji, 1973). Another unauthorized land use method may also represent building altered during construction deferent from the approved thereby contravening the provisions of the building regulations. Also, building development on Illegal Sites/land were also identified from the literature, however, lands originally reserved for open space like public parking, children play ground and leisure parks etc., in accordance with master plan now accommodate residential, private or commercial utilization with the cooperation, apathy or ineptitude of development control officers. In the same vein green areas along river courses are indiscriminately converted to residential plots. Sites of shopping centers, 
schools and places of worship also give way to residential use by the same act, to the end that resides of such areas suffer great costs for these illegal conversions. Akingboungbe and Folorunso (2005) posited that the control supervision and administration of construction processes in the country have been ridiculously loose despite adequate regulations put in place and advocated for the control mechanism to eradicate ineptitude. Fasakin (2002) refuted the notions that incidences of building failure in Nigeria were consequent on the fact that no regulation exist for monitoring quality and performance and averred that the notion was absolutely erroneous. Based on the above review on the residential land use pattern, there is a need examine the residential land use and development control system in orita-Obele housing estate, Akure.

\section{The Study Area: Orita Obele Housing Estate, Akure, Ondo -State}

This study was carried out in the private housing estate Akure, the capital of Ondo State. It is located some $311 \mathrm{~km}$ North East of Lagos, about $370 \mathrm{~m}$ above sea level and lies on longitude $5^{\circ} 18^{\prime}$ East and Latitude $7^{\circ} 17 /$ North of the Equator (Fig. 2 and Fig. 3).

The rapidity of the city's development within the last twenty-five years stemmed from the political status of the town which was initially a provisional headquarter and later a state capital thus serving as the seat of both the local and State Governments since 1976 (Akinluyi et al., 2019). This accounted for the influx of people to the city for employment and other related activities (Akinluyi et al., 2019). It is thus expected that the environmental situation would be critical in terms of the ability to meet up with the sporadic developments devoid of adequate planning and monitoring. In addition, the state has been classified as an oil-producing state while Akure has been classified as a Millennium Development City. All these factors are expected to greatly influence the population growth of the city. However, with the above developments, urban land use pattern needs to be investigated to collect existing data and make appropriate resolutions. This can be used to avert the future eruption of the non-habitability and environmental problems being suffered by bigger cities like Lagos, Purthacourt, Kano among others; as a result of inadequate planning at the inception of their growth and development. This becomes necessary now that the political and economic statuses with the accompanying population influx are influencing the development of in ondo state and Akure in particular. Hence, the choice of the study area is for the applicability to other cities in Nigeria and other developing countries.

Residential Planning and development also includes the connections-transportation such as roads, public facilities and utilities which coordinates all of this development with the natural environment that surrounds and enhances our communities. However, one of the most effective ways to create a livable community is to place residential areas and employment, commercial, service and recreational land uses as well as open space in close proximity (Akinluyi et al., 2019). This creates those choices where to live, where to work, where to shop and where to play in the park. Orita-Obele Housing Estate is located along Akure-Ijare Road, Akure. It is a privately owned housing estate (Fig. 4 and 1).

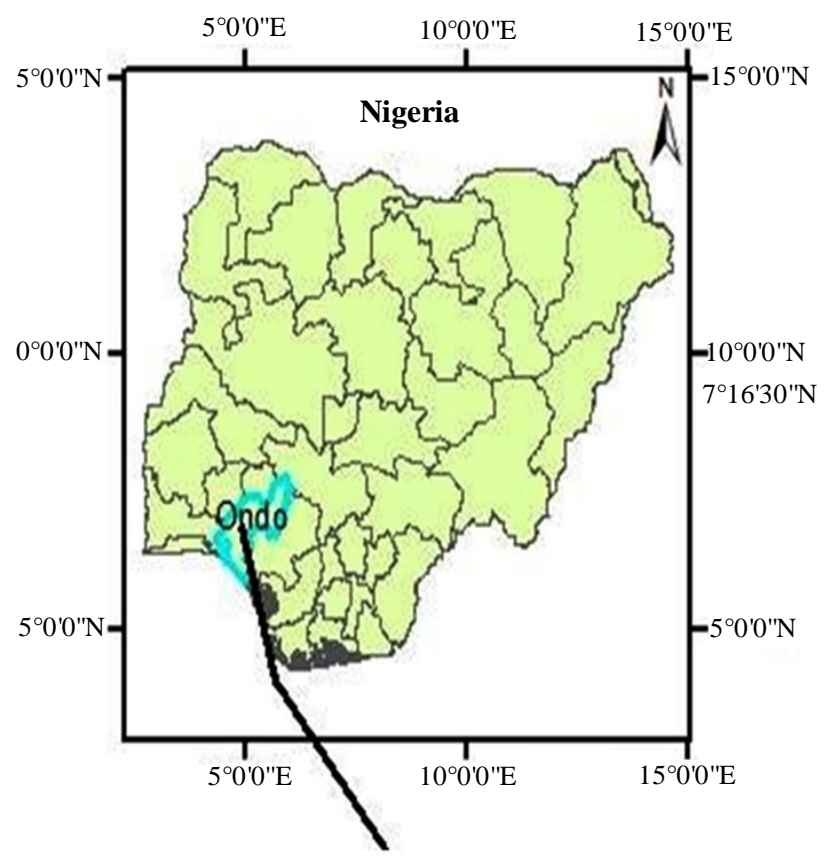

Fig. 1: Showing the location of ondo-state in Nigeria 
Muyiwa L. Akinluyi et al. / American Journal of Engineering and Applied Sciences 2020, 13 (3): 390.401 DOI: 10.3844/ajeassp.2020.390.401

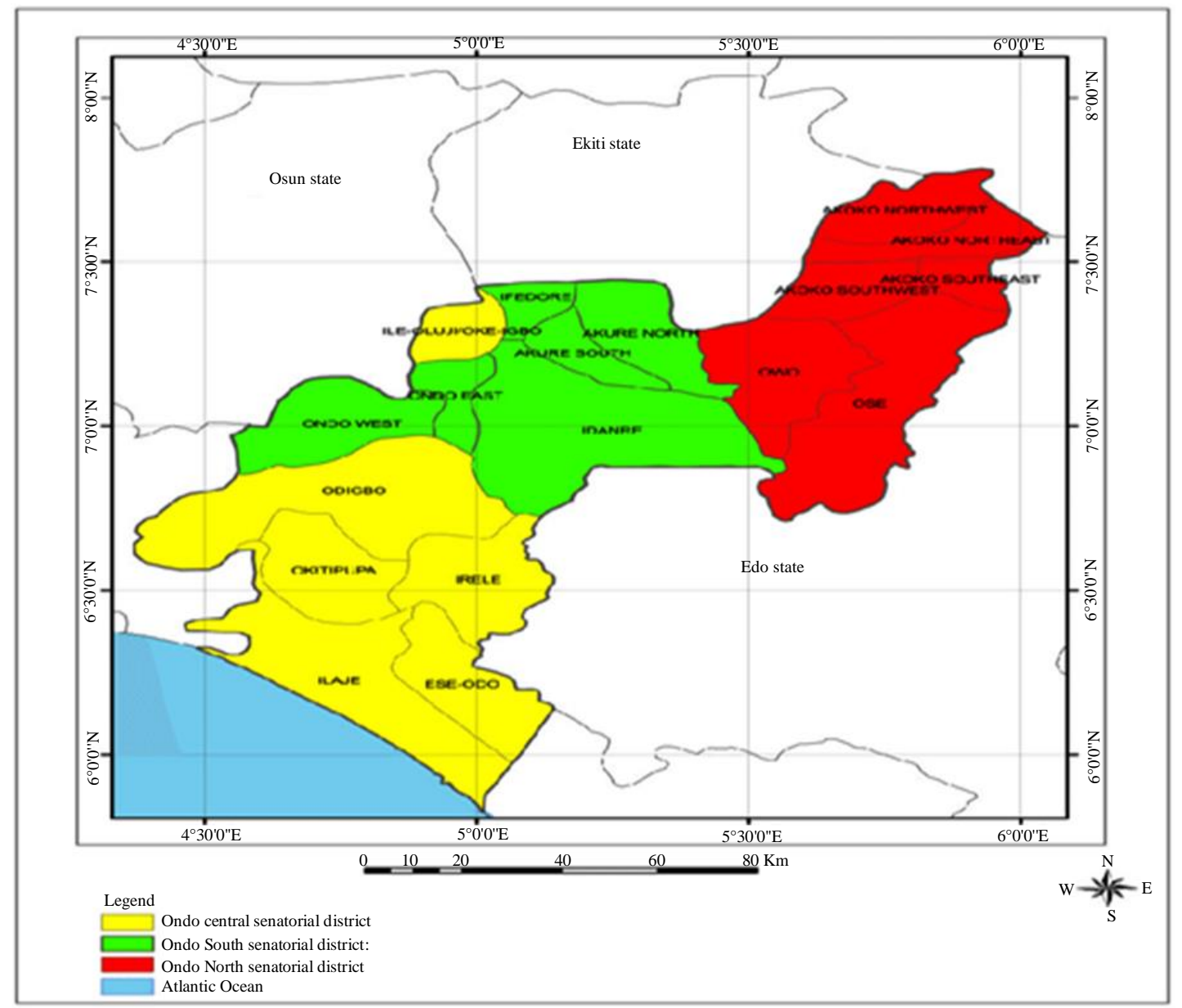

Fig. 2: Showing the location of Akure in ondo-state map

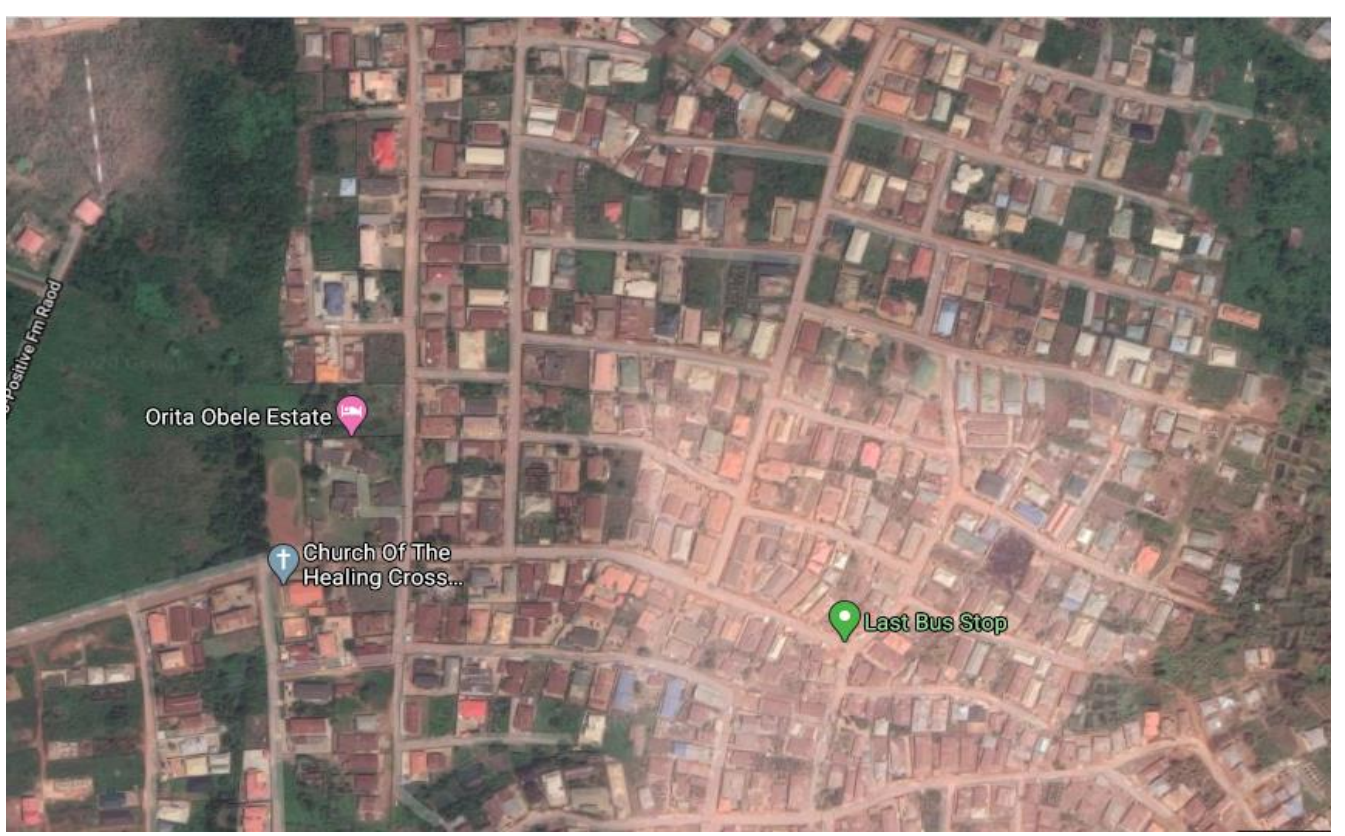

Fig. 3: Showing the location of akure in ondo-state map 


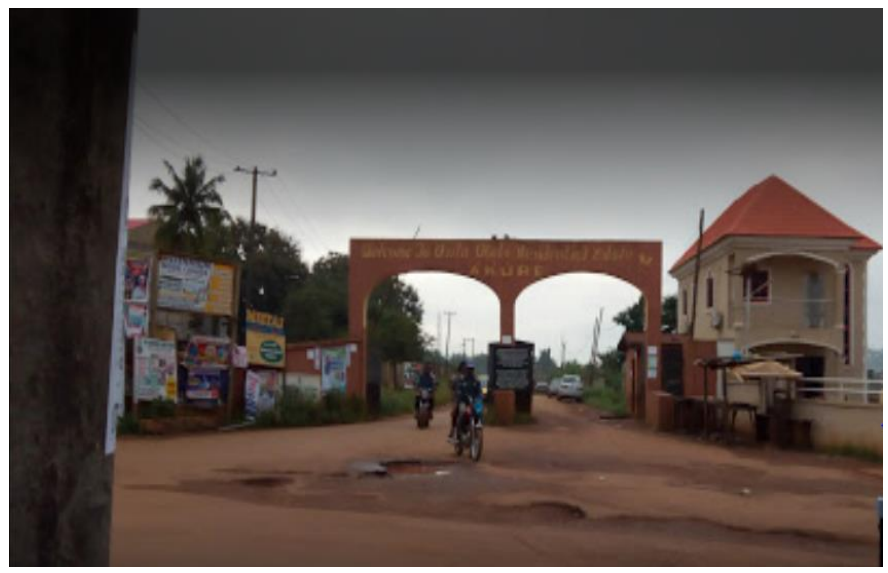

Fig. 4: Showing the Gate House of the Estate

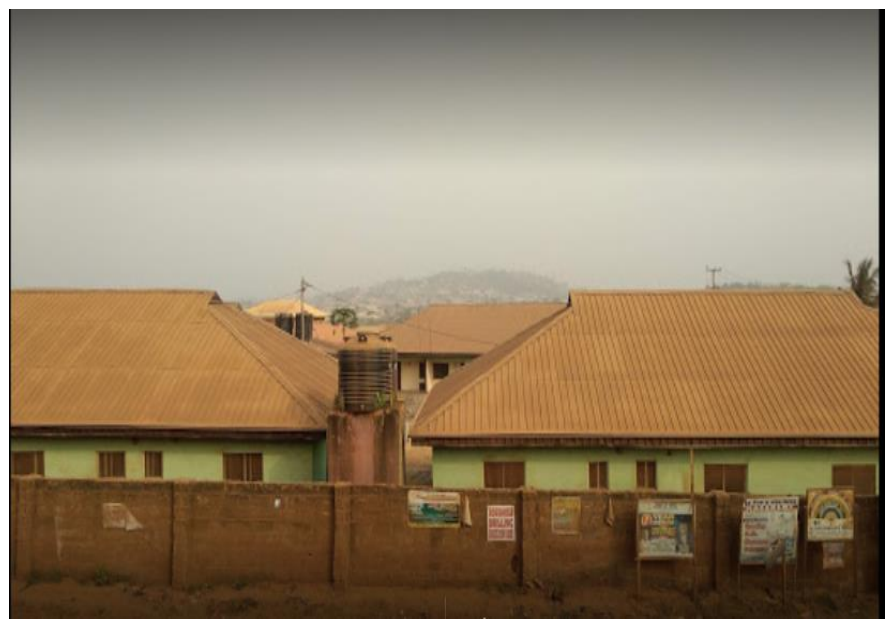

Fig. 5: Showing the Residential Buildings

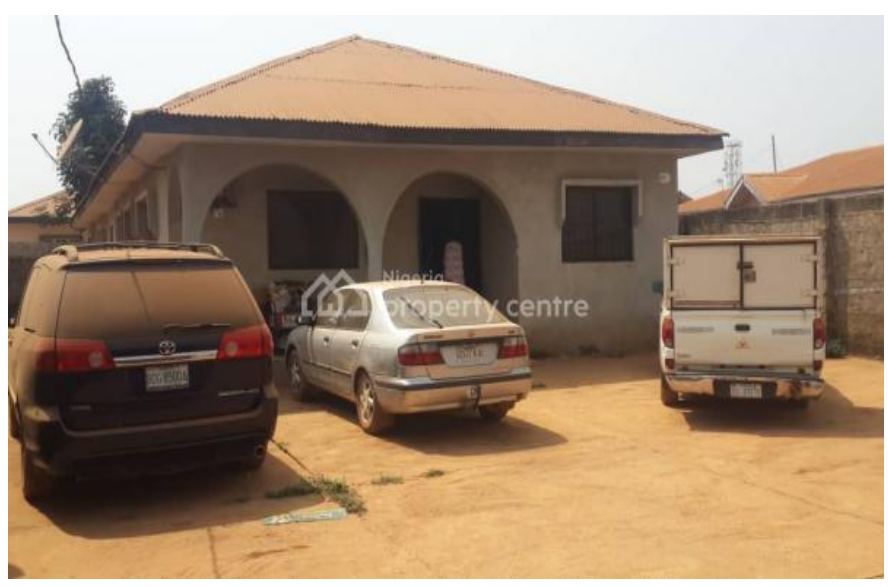

Fig. 6: Showing the Four-Bedroom

It has a total number of one thousand six hundred and ninety three $(1,683)$ housing unit such as three bedroom, two- bedroom, four bedroom, apartments flats such two and three bedroom semi-detached apartments, duplex buildings, flock of flats buildings among others Fig. 5 to 9 respectively. Land use in Orita-Obele estate were surveyed and cut into standard plots of $18 \times 36 \mathrm{~m}$ which were allocated to 
Muyiwa L. Akinluyi et al. / American Journal of Engineering and Applied Sciences 2020, 13 (3): 390.401 DOI: 10.3844/ajeassp.2020.390.401

individual to accommodate various building types for residential development and the sites were connected with road networks (Fig. 10 and 11 for undeveloped plots).

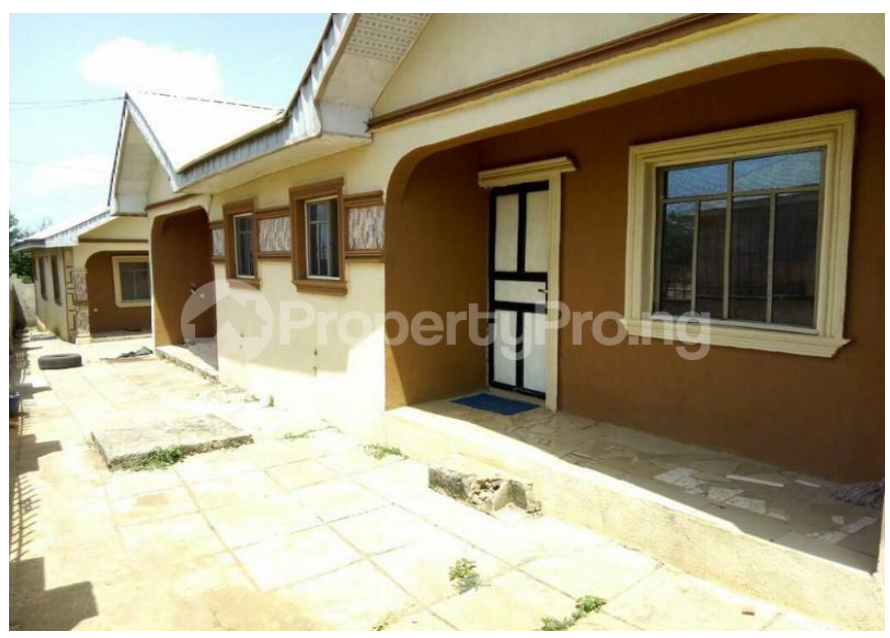

Fig. 7: Showing the 2-Bedroom Semi-Detached

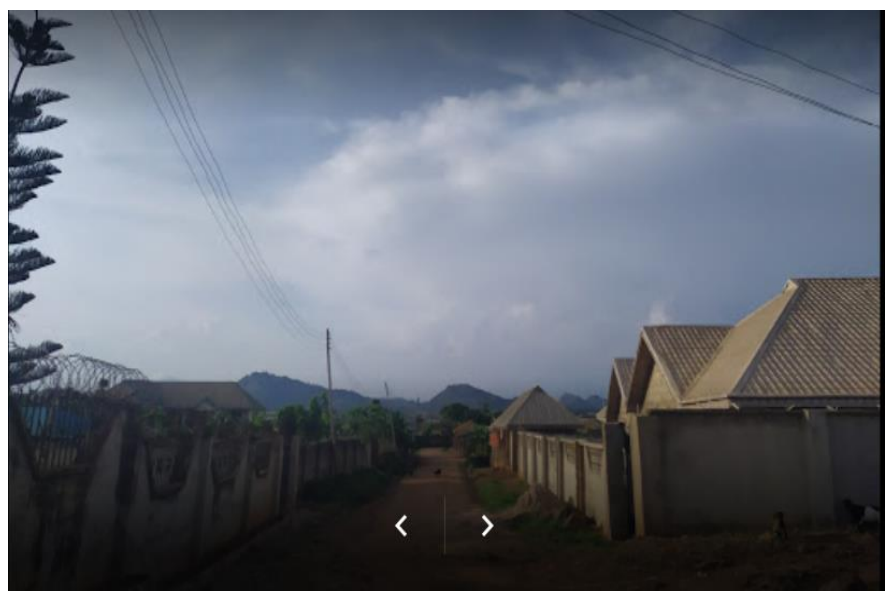

Fig. 8: Showing the access road to the streets

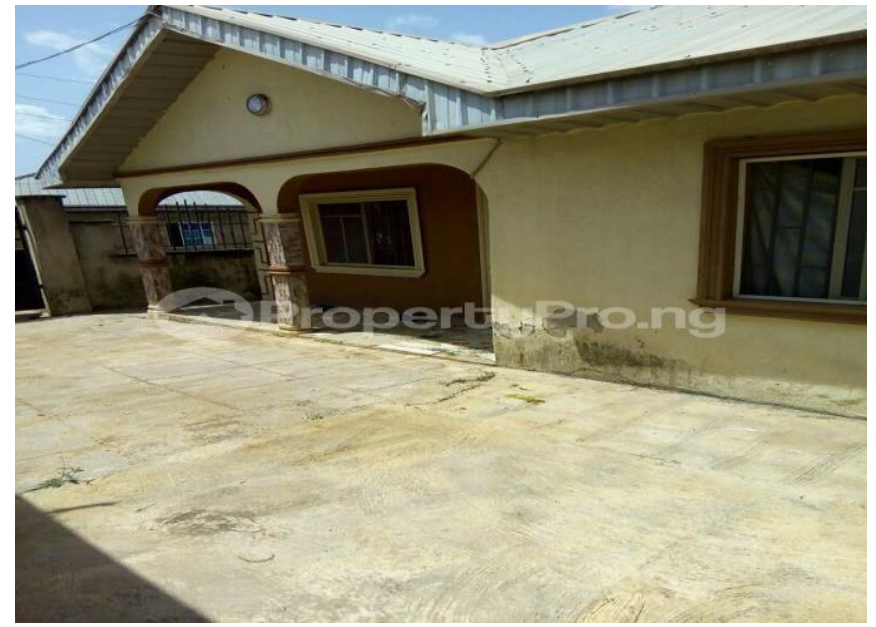

Fig. 9: Showing the two-Bedroom flat 


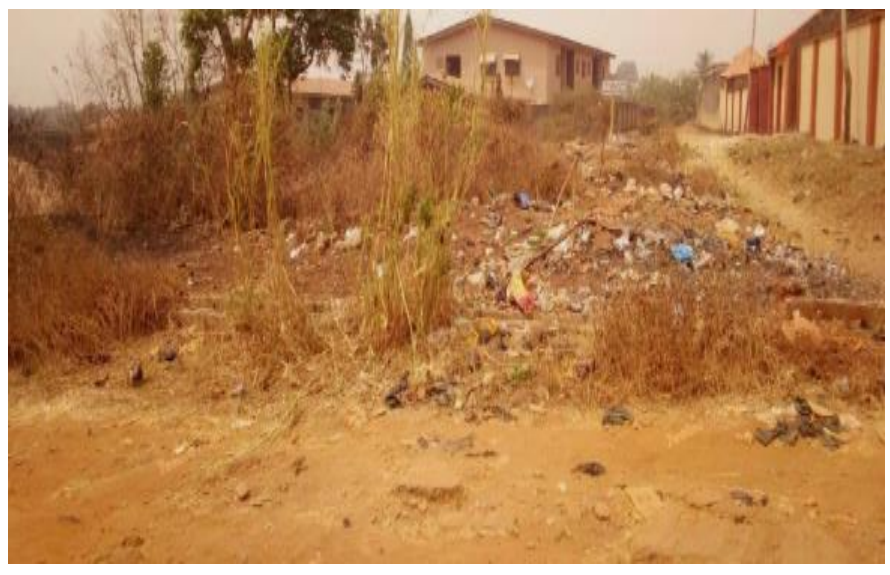

Fig. 10: Showing the Land Left Undeveloped

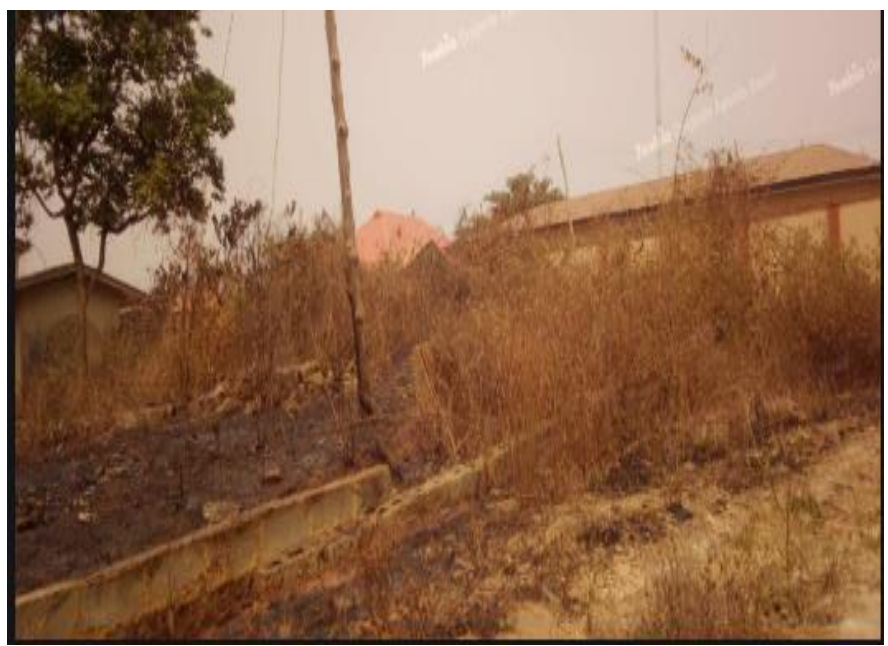

Fig. 11: Showing the Land Left Undeveloped

\section{Methodology}

This study was carried out in the residential environment in Orita-Obele housing estate. This estate is a privately managed housing estate. This study adopted survey method of data collection. Survey research provides a quantitative approach or numeric description of trends, attitudes or opinions of a population by studying a sample of that population. The survey design involves the use of close-ended questionnaires designed to cover parameters relating to different challenges involved in land use pattern and housing development control activities. Copies of these questionnaires were administered on the users of selected buildings in Orita-Obele housing estate. The justification for choosing field survey method for this study is that the data required are numerical, descriptive and explanatory. It was also evident from the literature, that most researchers adopted survey method and found it most suitable for research carried out in housing studies. The total housing units identified at Orita- Obele estates amounted to one thousand six hundred and ninety three (1,693). Systematic random sampling techniques at every 5 th buildings from each of the estates were adopted. Consequently, 5\% of the sample size was taken from the study area which amounted to eighty five (85) respondents selected at the study area. However, the total number of housing units where questionnaires were administered amounted to one hundred and sixty eighty (168) housing units. Data were analyzed using both descriptive and inferential statistics. Other important secondary data sources include; personal interviews, observation, journals, textbooks and internet facilities among others. However, maps of the study area were obtained and digitalized from the Google map.com and http//www.nigerinmuse.com respectively. Also, the statistics data were gotten from the study area. 


\section{Data Analysis and Interpretation}

This section discusses the essential factors relating to urban land use and various challenges involved in building development control with a view to providing information that will inform policy response to the methods of urban land use, building developments challenges and control in the residential environment in Akure, Nigeria. Field investigations as compiled on the residential units were analyzed and the research findings are discussed below.

Analysis from the Table 1 shows the number of plots acquired for housing development in the study area by residential land users. While $4.8 \%$ of respondents acquired less than 1 plot of land, majority of the respondents (53.6\%) acquired 1-3 plots of land. Furthermore, (14.3\%) acquired 3-4 plots of land, (9.8\%) acquired 4-5 plots of land, (6\%) acquired 5-6 plots of land, (3.7\%) acquired 7-8 plots of land for residential housing development.

Information from Table 2 indicates number of plots actually developed from the number of plots of land acquired in the study area. While (36.9\%) of respondents developed 1 plot of land, (20.2\%) developed 2 plots, (6\%) developed 3 plots of land, (10.7\%) developed 4 plots, (2.4\%) developed 5 plots, $(2.4 \%)$ developed 6 plots while $10.7 \%$ did not respond. It is evident that majority of the respondents developed 1-2 plots of land in the study area.

Analysis from Table 3 gives information about plots of land left undeveloped in the study area by the respondents. From the table, $19.1 \%$ of respondents left 1 plot undeveloped, $8.3 \%$ left 2 plots undeveloped, $1.2 \%$ left 4 plots undeveloped, $2.4 \%$ left 5 plots undeveloped while $26.2 \%$ did not respond. Apart from those that did not respond, it can therefore be deduced that majority of the respondents left 1 plot of land undeveloped (plates 10 and 11).

Table 4 gives information as whether the respondents in the estate have secured survey plan for their land. From the table, it is observed that $91.7 \%$ of respondents have the survey plan of their land while $6 \%$ do not have it. 2.4\% did not respond to the question. Therefore majority of the respondents have survey plan for their land in the study area.

Further analysis from Table 5 indicates respondents that have had their survey plan approved by surveyor general. It is observed that (86.9\%) of the respondents have their survey plan approved by the state surveyor general, $4.8 \%$ of respondents do not have their survey plan approved by the state surveyor general while $8.4 \%$ did not answer the question. Therefore, majority of the respondents (86.9\%) have approved survey plan in the study area.
According to the Table 6, while (84.5\%) of respondents have building plans, (3.6\%) do not have. $11.9 \%$ of respondents however did not respond to the question. Therefore, majority of the respondents in the study area have a building plan.

From the Table 7, 88.1\% of respondents acknowledged that their plans were approved by the town planning authority, $6.0 \%$ indicated that their plans were not approved by the town planning authority while $6.0 \%$ did not respond. Therefore majority of the respondents (88.1\%) did not only have building plan but also have the building plan approved by the town planning authority.

From the Table 8 , it can be seen that more people (51.24\%) affirmed that they involved a building professional while $19.32 \%$ indicated that they did not involve a building professional during the building development. Therefore substantial number of respondents $(51.24 \%)$ appreciates the importance of building professional and therefore engages their services during the building process in the study area.

Table 9 presents the level of challenge posed by undue delay in signing the survey plan from state surveyor general. While $53.6 \%$ of the respondents are of the belief that the challenges are very low, another $36.9 \%$ of the respondents also opined that the challenges are low. However, $2.4 \%$ of the respondents are of the opinion that the challenges encountered in signing survey plan are high and very high respectively. $4.8 \%$ of the respondents felt neutral about the challenge. It can therefore be deduced as attested by majority of the respondents (53.6 and $36.9 \%$ ) that there are minimal challenges posed by undue delay in signing the survey plan from state surveyor general in the study area.

Analysis from the Table 10 indicates level of challenges posed by undue delay in signing the final building plans for construction in the study area. While $5.7 \%$ of the respondents asserted that they encountered very high challenges in signing their final building plans for construction, another $9.5 \%$ of the respondents also opined that the challenges are high. On the contrary, $63.1 \%$ of the respondents are of the belief that the level of challenge posed by undue delay in signing the final building plan is low. Also $4.7 \%$ of the respondents are of the opinion that the challenges are very low. While $8.3 \%$ of the respondents felt neutral about the level of challenge posed by undue delay in signing the final building plans for construction.it can thus be concluded that level of challenge posed by undue delay in signing the final building plan for construction activities is low and very low as attested by majority of the respondents (63.1 and $4.7 \%)$ in the study area. 
Muyiwa L. Akinluyi et al. / American Journal of Engineering and Applied Sciences 2020, 13 (3): 390.401 DOI: 10.3844/ajeassp.2020.390.401

Table 1: Number of plots acquired

\begin{tabular}{|c|c|c|c|c|c|}
\hline & & Frequency & Percent & Valid Percent & Cumulative percent \\
\hline & Less than one Plot & 4.0 & 4.8 & 4.9 & 7.3 \\
\hline & 1 to 3 Plots & 45.0 & 53.6 & 54.9 & 62.2 \\
\hline & 3 to 4 plots & 12.0 & 14.3 & 14.6 & 76.8 \\
\hline & 4 to 5 plots & 8.0 & 9.5 & 9.8 & 86.6 \\
\hline & 5 to 6 plots & 5.0 & 6.0 & 6.1 & 92.7 \\
\hline & 7 to 8 plots & 3.0 & 3.6 & 3.7 & 96.3 \\
\hline & Others & 3.0 & 3.6 & 3.7 & 100.0 \\
\hline & Total & 82.0 & 95.2 & 100.0 & \\
\hline Missing & System & 4.0 & 4.8 & & \\
\hline Total & 84 & 100.0 & & & \\
\hline
\end{tabular}

Source: Statistical data obtained at the study area

Table 2: Number of plots developed

\begin{tabular}{|c|c|c|c|c|c|}
\hline & & Frequency & Percent & Valid Percent & Cumulative percent \\
\hline & 1 & 31 & 36.9 & 41.3 & 53.3 \\
\hline & 2 & 17 & 20.2 & 22.6 & 76.0 \\
\hline & 3 & 5 & 6.0 & 6.7 & 82.7 \\
\hline & 4 & 9 & 10.7 & 12.0 & 94.7 \\
\hline & 5 & 2 & 2.4 & 2.7 & 97.3 \\
\hline & 6 & 2 & 2.4 & 2.7 & 100.0 \\
\hline & Total & 75 & 78.6 & 100.0 & \\
\hline Missing & System & 18 & 21.4 & & \\
\hline Total & 84 & 100.0 & & & \\
\hline
\end{tabular}

Source: Statistical data obtained at the study area

Table 3: Number of plots undeveloped

\begin{tabular}{llcccc}
\hline & & Frequency & Percent & Valid Percent & Cumulative percent \\
\hline & 1 & 16.0 & 19.1 & 25.8 & 83.9 \\
& 2 & 7.0 & 8.3 & 11.3 & 95.2 \\
& 4 & 1.0 & 1.2 & 1.6 & 96.8 \\
Missing & 5 & 62.0 & 2.4 & 3.2 & 100.0 \\
Total & Total & 22.0 & 30.9 & 100.0 & \\
\hline
\end{tabular}

Source: Statistical data obtained at the study area

Table 4: Do you have survey plan of your land

\begin{tabular}{llcccc}
\hline & & Frequency & Percent & Valid Percent & Cumulative percent \\
\hline Valid & Yes & 77.0 & 91.7 & 93.9 & 93.9 \\
& No & 5.0 & 6.0 & 6.1 & 100.0 \\
Missing & Total & 82.0 & 97.6 & 100.0 & \\
Total & System & 2.0 & 2.4 & & \\
\hline
\end{tabular}

Source: Statistical data obtained at the study area

Table 5: Is your survey plan approved by state surveyor general

\begin{tabular}{llcccr}
\hline & & Frequency & Percent & Valid Percent & Cumulative percent \\
\hline & Yes & 73 & 86.9 & 89.0 & 93.9 \\
& No & 4 & 4.8 & 4.9 & 100.0 \\
Missing & Total & 82 & 91.6 & 100.0 & \\
Total & System & 7 & 8.4 & & \\
\hline
\end{tabular}

Source: Statistical data obtained at the study area 
Muyiwa L. Akinluyi et al. / American Journal of Engineering and Applied Sciences 2020, 13 (3): 390.401 DOI: 10.3844/ajeassp.2020.390.401

Table 6: Do you have building plans

\begin{tabular}{lllcrr}
\hline & & Frequency & Percent & Valid Percent & Cumulative percent \\
\hline & Yes & 71.0 & 84.5 & 87.7 & 96.3 \\
& No & 3.0 & 3.6 & 3.7 & 100.0 \\
Missing & Total & 81.0 & 88.1 & 100.0 & \\
Total & System & 10.0 & 11.9 & & \\
\hline
\end{tabular}

Source: Statistical data obtained at the study area

Table 7: Is your building plan approved by the town planning authority

\begin{tabular}{llcccr}
\hline & & Frequency & Percent & Valid Percent & Cumulative percent \\
\hline & Yes & 74 & 88.1 & 91.4 & 93.8 \\
& No & 5 & 6.0 & 6.2 & 100.0 \\
Missing & Total & 81 & 94 & 100.0 & \\
Total & System & 5 & 6.0 & & \\
\hline
\end{tabular}

Source: Statistical data obtained at the study area

Table 8: "Did you involve any building professional during the building development process

\begin{tabular}{llllll}
\hline & & Frequency & Percent & Valid percent & Cumulative percent \\
\hline Valid & NO & 23 & 19.32 & 19.32 & 19.32 \\
& YES & 61 & 51.24 & 51.24 & 51.24 \\
& Total & 84 & 100.0 & 100.0 & \\
\hline
\end{tabular}

Source: Statistical data obtained at the study area

Table 9: Level of challenge posed by undue delay in signing the survey plan from state surveyor general

\begin{tabular}{llccr}
\hline & & Frequency & Percent & Valid percent \\
\hline Valid & Very Low & 45 & 53.6 & 53.6 \\
& Low & 31 & 36.9 & 36.9 \\
& Neutral & 4 & 4.8 & 4.8 \\
& High & 2 & 2.4 & 2.4 \\
& Very High & 2 & 2.4 & 2.4 \\
Missing & Total & 84 & 84.0 & 100.0 \\
Total & System & 0 & 00 & \\
\hline
\end{tabular}

Source: Statistical data obtained at the study area

Table 10: level of challenge posed by undue delay in signing the final building plans for construction

\begin{tabular}{llccr}
\hline & & Frequency & Percent & Valid percent \\
\hline Valid & Very Low & 4 & 4.7 & 5.1 \\
& Low & 53 & 63.1 & 68.8 \\
& Neutral & 7 & 8.3 & 9.0 \\
& High & 8 & 9.5 & 10.4 \\
Missing & Very High & 5 & 5.7 & 6.5 \\
Total & Total & 77 & 91.6 & 100 \\
\end{tabular}

Source: Statistical data obtained at the study area

Table 11: Logistic regression analysis of variable

\begin{tabular}{lllllllll}
\hline & Independent variables & B & S.E. & Wald & Df & Sig. & Exp (B) & Relationship with Q38 \\
\hline Step 1 $^{\text {a }}$ & Q9 & -42.982 & 578489.155 & & 0.000 & 1.000 & 1.000 & 2.15452 E-19 negative relationship \\
& Q10 & 27.008 & 600299.874 & 0.000 & 1.000 & 1.000 & $5.36519 E+11$ & Positive relationship \\
& Constant & -10.577 & 279226.174 & 0.000 & 1.000 & 1.000 & 2.54977 E-05 & Negative relationship \\
\hline
\end{tabular}

In Table 11, the numbers in the Exp (B) column show the odds ratio of the corresponding covariate (independent variable) which is shown in the independent variable column. If the odds ratio is less than one, this means there is a negative relationship between the corresponding covariate (independent variable) and the dependent variable (Q8). On the other hand, if the odds ratio is greater than one, this means 
there is a positive relationship between the corresponding covariate (independent variable) and the dependent variable (Q8). Q8 asks the question of whether the respondent involved a building professional or not during the building development. This means that all the independent variables that showed a negative relationship will in fact reduce the probability of a person involving a building professional. On the other hand, all the independent variables that showed a positive relationship will in fact reduce the probability of a person involving a building professional (Table 11).

\section{Conclusion}

This study was conducted to assess urban residential land use, development challenges and control in Orita Obele housing estate, Akure ondo-state Nigeria. The study was carried out through primary method of investigation to explore the various challenges involved in residential land use pattern and development strategies with a view to providing information that will inform decision making on land and building development in the study area. However, the following deductions were made based on the information obtained from the field study; majority of the land owners $(53.5 \%)$ acquired between (1) one and (3) three plots of land for their housing development in the study area and many of these residential land users $(36.9 \%)$ and $(20.2 \%)$ developed only (1) one and (2) two plots respectively for residential purpose. It was also evidence from the field study carried out that majority $(86.9 \%)$ of the land owners had gone through the approval processes of their survey by signing their survey plan with the Ondo state surveyor general. This is an indication that the owners of the land are more educated and enlightened on the importance of survey plan approval. Although, $36.9 \%$ of the land owners claimed that there were undue delay in signing the survey plan from state surveyor general but had relatively low influence on their housing development. In addition, (84.5\%) of the building owners in Orita Obele housing estate are aware of the importance of producing building plan and therefore, they all have building plans for their residential buildings. Furthermore, $(88.1 \%)$ of the building owners have succeeded in approving their building plans with the urban and regional town planning authority in Akure while only (51.24\%) involved a building professional during the building development. However, $(63.1 \%)$ of the land owners claimed that there were delay in signing the building plan from appropriate authority as stated above but had relatively low influence on their housing development.

The results from this study suggested more affordable residential land to be provided by the state government or stakeholders for adequate and proper planning of the housing environment to give room for more quality air space and comfort within the environment. However, results from personal observation shows that more number of buildings that serves different purposes was identified on a plot of land. Government should make provision for adequate land and housing development loan through mortgage bank; these will help individual developers to develop more land for adequate housing provisions thereby improving the users' well being and quality of life.

These are not appropriate considering the amount of air space needed for quality of life, such as adequate air space and comfort within the environment. It is also recommended that more professionals be employed for adequate monitoring of building approval process. The required authorities for both survey and building plan should facilitate the prompt release of the approved drawings and survey. Therefore, these will not have unnecessary delay during the building construction process.

This study had greatly succeeded in examining the various processes and challenges involved in land acquisition process and its approval. It provides information that will inform policy response for urban land use, development challenges and control in Orita Obele Housing Estate, Akure, Nigeria.

\section{Acknowledgement}

I acknowledged and appreciate the almighty God for the opportunity given in writing this article. I also appreciate the efforts of all the authors for their immense contributions toward the successful publication of this article. Their various wealth of experience had really improved this article. Lastly, the greatest thanks go to the reviewers of this article, who have spared their various time to review this article and ensure the betterment of this research work.

\section{Author's Contributions}

Muyiwa L. Akinluyi: Had contributed towards the Conceptualization of the research Ideology, identification of problem statement, setting the aim and objectives, data gathering and analysis of this research work.

Oluwatoyin $\mathbf{O}$. Adeleye: Had contributed by reviewing the relevant literatures relating to urban residential urban studies relating to Architecture, data gathering and analysis.

OLA Olumide S: Contributed to the literature relating to housing and land use management data gathering and analysis.

Akinniyi Tunde Akinyemi: Contributed to the literature relating to building approval standard, development control and physical planning.

\section{Ethics}

This article is original and contains unpublished material. The Authors declare that the article is void of 
ethical issues and no conflict of interest will arise after the publication of this manuscript.

\section{References}

Adedeji, A. (1973). Urbanization Challenges in NigeriaA Race Against Time. In: Management problems of rapid urbanization in Nige. Ile-Ife, University of IleIfe, University of Ife Press.

Akingbohungbe, D. O. (2005). Development Control and Urban Growth in Nigeria Medium-Sized cities: An Appraisal of Akure Township Experience. Journal of Environmental Studies, 1(1), 8-13.

Akingbohungbe, D. O., \& Folorunso, C. O. (2005). Divergence Between Theory and Practice of Architecture in Nigeria. In The Nigerian Academic Forum (Vol. 8, No. 2, pp. 6-10).

Akinluyi, M. L., \& Adedokun, A. (2014). Urbanization, Environment and Homelessness in the Developing world: The Sustainable Housing Development. Mediterranean Journal of Social Sciences, 5(2), 261-261.

Akinluyi, M. L., Ogunruku, M. P., Adu, C., \& Ola, O. S. (2019). Methods of Land Acquisition and Approval for Housing Development in Selected Residential Environment Akure, Nigeria. Methods, 6(2).

Chukwujekwu, I. E. (2006). Facilitating low cost housing scheme: Which way forward. The Journal of the Association of Housing Corporations of Nigeria, 1(10), 45-52.
Fasakin, J.O. (2002). Building collapse in Ondo State of Nigeria-preventive town planning standards and regulations. An invited paper. In: The building collapse-causes, prevention and remedies, A Book of Reading of the Nigerian Institute of Builders, OndoState, pp; (40-49).

FRN. (1992). The Nigerian Urban and regional planning degree 88. Lagos Federal Government Press.

Mayaki, S. (2007). Urbanization and housing development in Nigeria: The journey so far. In: Private sector driven housing delivery, Issue, Challenges and Prospects, Department of Estate Management, University of Lagos, Akoka, Lagos, Nigeria, pp; (78-87).

Olomolaiye, P. (1999). Rural Housing in NigeriaConcept, Problems and Functional Approach. Journal of.

Omirin, M. M. (2002). Issues in land accessibility in Nigeria. In Proceedings of a National Workshop on Land Management and Property Tax Reform in Nigeria.

Owoeye, J. O., \& Adedeji, Y. M. D. (2015). Urban land acquisition for sustainable housing delivery in Akure, Nigeria. International Journal of Developing Societies, 4(1), 10-20.

Robert, B. Y. (1975). A Systematic Approach to Planning Occupational Programs. Community College Review. Sage Journal First Published September 1, 1975. 